\title{
Transvesical Prostatectomy after Transurethral Resection- Need for Retention of Skills for Open Prostatectomy: A Case Report
}

\author{
Balantine U. Eze, Anthony C. Nevo, Chijioke C. Anekpo, and Sunday G. Mba
}

\section{ABSTRACT}

Benign prostatic hyperplasia is a common cause of bladder outlet obstruction BPH. Transurethral resection of prostate (TURP) remains the gold standard of surgical therapy but have limitations in handling large prostates. We report a case of a patient with a large prostate that had TURP, later developed acute urinary retention and subsequently had transvesical prostatectomy with a good outcome. There is need for retention of skills for open prostatectomy despite the crave for acquisition of endoscopic/ minimally invasive skills.

Keywords: BPH, Open prostatectomy, Skill retention, TURP.

Submitted : June 18, 2021

Published : July 13, 2021

ISSN: $2593-8339$

DOI: $10.24018 /$ ejmed.2021.3.4.940

\section{B. U. Eze*}

Department of Surgery, College of Medicine, Enugu State University of Science and Technology, Enugu, Nigeria.

(e-mail: balantine.eze@esut.edu.ng)

A. C. Nevo

Department of Surgery, College of Medicine, Enugu State University of Science and Technology, Enugu, Nigeria.

(e-mail: eldanevo@yahoo.com)

C. C. Anekpo

Department of Otorhinolaryngology, College of Medicine, Enugu State University of Science and Technology, Enugu, Nigeria.

(e-mail: chijioke.anekpo@esut.edu.ng) S. G. Mba

Department of Obstetrics and Gynaecology, College of Medicine, Enugu State University of Science and Technology, Enugu, Nigeria.

(e-mail: redeemedsunny ${ }^{\circledR}$ yahoo.com)

*Corresponding Author

need to acquire and retain skills for open prostatectomy.

\section{INTRODUCTION}

Benign prostatic hyperplasia $(\mathrm{BPH})$ is a common cause of bladder outlet obstruction (BOO) in ageing males [1]. With symptom progression, failure of medical therapy and onset of complications surgery may be required [2], [3]. Surgical therapy for BPH may be either by open or endoscopic/minimal access routes [4], [5]. In recent times many minimal access procedures for surgical treatment of $\mathrm{BPH}$ abound but transurethral resection of prostate (TURP) remains the gold standard of surgical therapy [6]. The major constraint in the use of TURP as a surgical option of treatment lies in the fact that it cannot safely be used for treatment of prostate glands $>100 \mathrm{~g}$ [7], [8]. Large prostates and resection time > 90 minutes increases the risk for TURP syndrome [7], [9].

We presented a case of a patient who developed acute urinary retention (AUR) following TURP and emphasized the

\section{CASE Report}

Mr A.C is a 68-year-old hypertensive patient who spends most of his time in the United States and some of his time here in Nigeria. He had a history of BOO that was attributable to an enlarged prostate. Digital rectal examination showed an enlarged prostate with benign features, abdominal ultrasound estimated prostate size of $388 \mathrm{~g}$ and serum prostate specific antigen of 30.5 nanogram $/ \mathrm{ml}$. Subsequently, he had a digital guided transrectal prostate biopsy that revealed a histologic diagnosis of benign prostate tissue. Following failure of his symptoms to improve, he was counselled for transvesical prostatectomy mainly because of the size of his prostate and partly because of the absence of appropriate minimally invasive/ endoscopic procedure in our facility and he declined. He travelled back to the United States and had a 
TURP. Six months on, while on a visit to Nigeria, he developed AUR necessitating a visit to the accident and emergency department of Enugu State University of Science and Technology Teaching Hospital, Enugu. On presentation, he was found to be in painful distress with temperature of $37.30{ }^{\circ} \mathrm{C}$, pulse rate of 97 beats per minute and blood pressure of $165 / 98 \mathrm{~mm} \mathrm{Hg}$. He had suprapubic distention and was easily catheterized with two-way size $18 \mathrm{~F} 100 \%$ silicon catheter with egress of 1100 milliliters of clear urine. Subsequently, he was re-evaluated and had open transvesical prostatectomy 2 weeks after presentation in the emergency department. The weight of enucleated prostate gland was $207.88 \mathrm{~g}$ (Fig. 1). The post-operative period was uneventful, and he had successful trial void without catheter on the 10th post-operative day. He has been followed up for 15 months and still voids well and has no complaints.

\section{DISCUSSION}

With the crave in developing countries for acquisition of technology and skills for TURP and other endoscopic surgical treatment options for $\mathrm{BPH}$, there is still needed to teach and retain skills for open prostatectomy. This is necessary as research have shown that the prostate size of blacks is significantly more than that of Caucasians [10]. Open prostatectomy will still remain an important option of surgical management of BPH in some selected cases like the case we presented. Our patient developed AUR despite having had TURP because of his large prostate size.

In the index patient, if minimally invasive surgical therapy was to be considered, holmium laser enucleation of the prostate would have been better as it is an appropriate option for endoscopic surgical treatment for large prostate glands [11]. The problem is that it is exorbitant and our patient, probably because of not having a health insurance, might not have been able to afford the cost in the United States. This might have made his diaspora surgeons to offer him TURP despite clear knowledge that a single stage TURP could not have been able to solve all his problems [12]. Open prostatectomy would have been an affordable option but the skills for its performance might have not be available [13]. There is discrepancy in the availability of skill for open prostatectomy with developed countries having lost the skill due to popularity of endoscopic procedures [14]. Developing countries also run the risk of losing skills for open prostatectomy as we embrace newer endoscopic procedures.

\section{CONCLUSION}

Open prostatectomy is still a viable surgical option for treatment of BPH in selected cases. Despite the great interest for the development of TURP in developing countries like Nigeria, there is still need for the retention of skills for open prostatectomy as TURP and other endoscopic surgical treatment is not the panacea for all case of BPH.

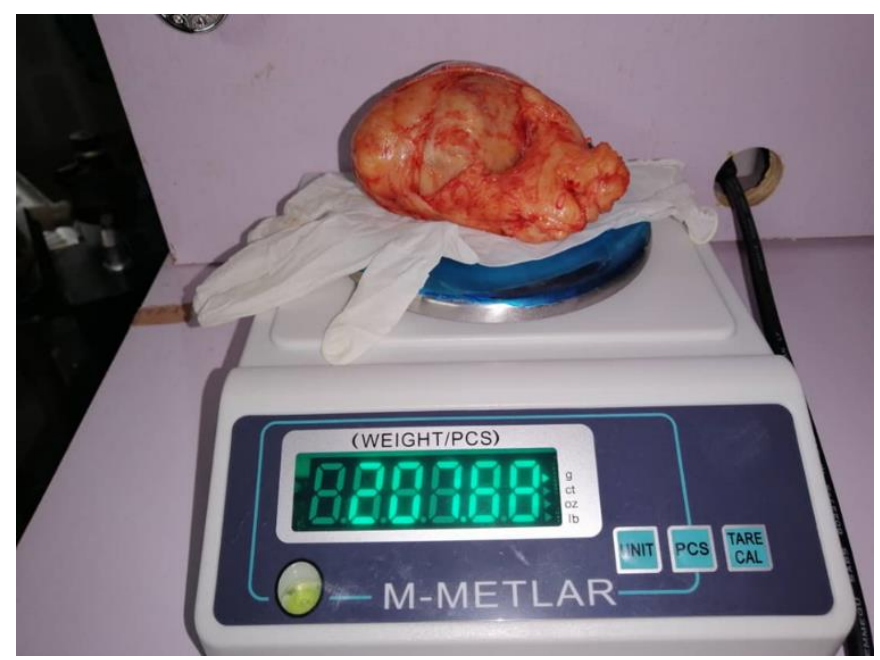

Fig. 1. Enucleated prostate gland.

\section{REFERENCES}

[1] P. Boyle, R. McGinn, P. Maisonneuve, and C. La Vecchia, "Epidemiology of benign prostatic hyperplasia: present knowledge and studies needed," European urology, vol.20, pp. 3-10, 1991.

[2] A. Berra, P. Lázaro, K. Fitch, A. Martin, and L. Calahorra, "Appropriate indications for surgery of benign prostatic hyperplasia," InISTAHC 11th Annual Meeting, pp. 4-7, Stockholm, Sweden, Jun. 1995.

[3] J. Braeckman, and L. Denis, "Management of BPH then 2000 and now 2016-From BPH to BPO," Asian journal of urology, vol. 4, no. 3, pp. 138-147, July 2017.

[4] M. R. Macey, and M. C. Raynor MC, "Men's Health: Medical and Surgical Treatment Modalities for Lower Urinary Tract Symptoms in the Male Patient Secondary to Benign Prostatic Hyperplasia: A Review," Seminars in interventional radiology, vol.33, no. 3, pp. 217 , Sep. 2016.

[5] B. Rocco, G. Albo, R. C. Ferreira, M. Spinelli, G. Cozzi, P. Dell'Orto, V. Patel, and F. Rocco, "Recent advances in the surgical treatment of benign prostatic hyperplasia," Therapeutic advances in urology, vol. 3 , no. 6, pp. 263-272, Dec. 2011.

[6] E. K. Mayer, S. G. Kroeze, S. Chopra, A. Bottle, and A. Patel, "Examining the 'gold standard': a comparative critical analysis of three consecutive decades of monopolar transurethral resection of the prostate (TURP) outcomes," BJU international, vol. 110, no. 11, pp. 1595-1601, Dec. 2012.

[7] Stolzenburg J-U, Ho KM., Schwalenberg T, Hohenfellner R. Transurethral Resection of the Prostate. In: Manual Endourology. 2005. p. 77-87.

[8] A. Lee, H. J. Lee, and K. T. Foo, "Can men with prostates sized $80 \mathrm{~mL}$ or larger be managed conservatively?", Investigative and Clinical Urology, vol. 58, no. 5, pp. 359-364, 2017.

[9] N. P. Gupta, and R. Nayyar, "Management of large prostatic adenoma: Lasers versus bipolar transurethral resection of prostate," Indian Journal of Urology, vol. 29, no. 3, pp. 225, Jul. 2013.

[10] J. S. Kang, S. J. Maygarden, J. L. Mohler, and R. S. Pruthi, "Comparison of clinical and pathological features in African-American and Caucasian patients with localized prostate cancer," $B J U$ International, vol. 93, no. 9, pp. 1207-1210, Jun. 2004.

[11] M. Yucel, B. Ara, S. Yalcinkaya, N. K. Hatipoglu, and E. Aras, "Conventional monopolar transurethral resection of the prostate in patients with large prostate ( $\geq 80$ grams)" Central European Journal of Urology, vol.66, no.3, pp. 303-308, 2013.

[12] C. Persu, D. Georgescu, I. Arabagiu, V. Cauni, C. Moldoveanu, and P. Geavlete, "TURP for BPH. How large is too large?" Journal of Medicine and Life, vol. 3, no. 4, pp. 376-380, Nov. 2010.

[13] Z. Okhunov, S. Safiullah, R. Patel, S. Juncal, H. Garland, N. R. Khajeh, J. Martin, T. Capretz, C. Cottone, M. L. Jordan, and E. McDougall, "Evaluation of urology residency training and perceived resident abilities in the United States," Journal of Surgical Education, vol. 76, no. 4, pp. 936-948, Jul. 2019.

[14] P. Levasseur-Fortin, K. W. Law, D. D. Nguyen, A. Zakaria, V. Misrai, D. Elterman, N. Bhojani, E. Rijo, and K. C. Zorn, "National discrepancies in residency training of open simple prostatectomy for benign prostatic enlargement: Redefining our gold standard," Canadian Urological Association Journal, vol. 14, no. 6, pp. 182-186, Jun. 2020. 